\title{
Retraction Note to: Solutions of the Dirichlet-Schrödinger problems with continuous data admitting arbitrary growth property in the boundary
}

Jianjie Wang ${ }^{1 *}$, Jun $\mathrm{Pu}^{2}$ and Ahmed Zama ${ }^{3}$

The original article can be found online at https://doi.org/10.1186/ s13662-016-0751-4

"Correspondence: jianjiewang81@163.com

${ }^{1}$ College of Applied Mathematics, Shanxi University of Finance and Economics, Taiyuan, China Full list of author information is available at the end of the article

\section{Retraction}

The Editors-in-Chief have retracted this article [1] because it significantly overlaps with an article by different authors [2] that was simultaneously under consideration at a different journal. The article also shows evidence of authorship manipulation and peer review manipulation. In addition, the identity of the third author could not be verified: the University of Mosul has confirmed that Ahmed Zama has not been affiliated with their institution. The authors have not responded to any correspondence regarding this retraction.

\section{Author details}

${ }^{1}$ College of Applied Mathematics, Shanxi University of Finance and Economics, Taiyuan, China. ${ }^{2}$ Center for Finance and Accounting Research, University of International Business and Economics, Beijing, China. ${ }^{3}$ Department of Computer Engineering, College of Engineering, University of Mosul, Mosul, Iraq.

\section{Publisher's Note}

Springer Nature remains neutral with regard to jurisdictional claims in published maps and institutional affiliations.

Published online: 02 April 2020

\section{References}

1. Wang, J., Pu, J., Zama, A.: Solutions of the Dirichlet-Schrödinger problems with continuous data admitting arbitrary growth property in the boundary. Adv. Differ. Equ. 2016, 33 (2016). https://doi.org/10.1186/s13662-016-0751-4

2. Xue, G., Wang, J.: An application of the inequality for modified Poisson kernel. J. Inequal. Appl. 2016, 24 (2016). https://doi.org/10.1186/s13660-016-0959-6

\section{Springer}

(c) The Author(s) 2020. This article is licensed under a Creative Commons Attribution 4.0 International License, which permits use, sharing, adaptation, distribution and reproduction in any medium or format, as long as you give appropriate credit to the original author(s) and the source, provide a link to the Creative Commons licence, and indicate if changes were made. The images or other third party material in this article are included in the article's Creative Commons licence, unless indicated otherwise in a credit line to the material. If material is not included in the article's Creative Commons licence and your intended use is not permitted by statutory regulation or exceeds the permitted use, you will need to obtain permission directly from the copyright holder. To view a copy of this licence, visit http://creativecommons.org/licenses/by/4.0/ 